\title{
The Subcontinent Falls Apart: Communal Violence and Religious Intolerance in Khushwant Singh's Train to Pakistan
}

\author{
Md Abu Shahid Abdullah \\ Assistant Professor, Department of English \\ East West University, Dhaka, Bangladesh \\ Email: sabdullah@ewubd.edu
}

https://doi.org/10.3126/litstud.v34i01.39530

Abstract

The aim of the article is to show the breakdown of trust and harmony among people from different religious and communal background caused by the partition as depicted in Khushwant Singh's Train to Pakistan. The article also focuses on the way the novel criticises the indifference of men with power and authority, and the passivity and fear of social, political and religious leaders over the communal violence during and after the partition. Last but not the least, the article also highlights the way the novel portrays the love between a Sikh boy and a Muslim girl where the Sikh boy Juggut Singh sacrifices himself in order to save his beloved Nooran and consequently saves the life of thousands of Muslims targeted for massacre.

Keywords: communal violence, trauma, partition, love, religious intolerance

\section{Introduction}

The partition of the Indian subcontinent, which caused the largest exodus of people in the history of human kind and is considered as one of the most traumatic events of the recent history, is marked by its brutality, oppression and resulting trauma. The partition, which created a deep psychological estrangement between different Indian communities (namely, Hindu, Muslim and Sikh) and transformed into a collective trauma, left a deep scar which cannot be erased from the historical records. The partition disrupted the Indian mindset as well as its social structure and brought a long and rich communal history to a sudden end. Khushwant Singh's Train to Pakistan, which was originally published as Mano Majra, is a stunning picture of the partition covering its bloodshedding days. Khushwant Singh vividly describes the ways the declaration of partition gives rise to suffering and frustration in Mano Majra - a small village situated on the bank of River Sutlej in the border between India and Pakistan used as a microcosm of communal violence of the partition days. Singh graphically shows how the announcement of partition between India and Pakistan transformed the peaceful village 
into a battlefield full of riots, mass murder, gang-rape and all sorts of inhuman activities. Singh shows the collapse of human, social and ethical values caused by the cruelty demonstrated by both sides, sending people in a hysterical situation. The same people who had shown mutual respect, honesty and unity in the past were the victims of disrespect, dishonesty and chaos in the time of partition.

The independence of Indian subcontinent from British rule in 1947 and the whimsical splitting of the nation into two countriesMuslim dominated Pakistan and Hindu dominated India - is the most significant event in the history of modern India. The traumatic experience of the partition troubled Khushwant Singh to the deep of his heart and shattered his belief concerning mankind and humanity. The declaration of independence became a shameful debacle as Muslims, Hindus and Sikhs frenziedly turned on each other. The birth of twinsIndia and Pakistan - was full of violence and suffering. An approximate number of ten million people crossed a sketchy line drawn by a falling empire. By hiding treasures, gathered over generation, in pieces of clothes, migrating people ran in opposite directions - Hindus to the East and Muslims to the West. Houses were robbed, villages were left abandoned, men were brutally murdered and women were gang-raped and then killed. The geography of the entire subcontinent was soaked in blood. In describing partition, Urvashi Butalia says:

The political partition of India caused one of the great human convulsions of history ... twelve million people moved between the new, truncated India and the two wings, East and West, of the newly created Pakistan . . . Estimates of the dead vary from 200,000 to two million but that somewhere around a million people died is now widely accepted . . 75,000 women are thought to have been abducted and raped by men of religious difference from their own [and indeed sometimes by men of their own religion]. (3)

Butalia's statement clearly depicts the horrific violence of the partition.

The novel Train to Pakistan is divided into four sections: "Dacoity,"“Kalyug,"“Mano Majra" and "Karma." In the first section, the killing of Ram Lal, the only Hindu inhabitant of Mano Majra, by a gang of robbers initiates the main tragedy of the novel. The second section shows the disruption of the peace of the old world with the arrival of train from Pakistan carrying dead bodies. The third section revolves around a transformed Mano Majra, which has lost its serenity and isolation and got involved in national devastation. The fourth and last section focuses on the importance of love and sacrifice in the midst 
of violence where a Sikh boy Juggut Singh sacrifices his life in order to save the life of her Muslim girlfriend Nooran as well as the lives of thousands of other Muslims. The aim of the article is to show the breakdown of trust and harmony among people from different religious and communal background caused by the partition as depicted in the novel. By using the village Mano Majra as the microcosm of the entire Indian subcontinent, the novel effectively focuses on the loss of life and assets and dislocation by the people of different religious background for their independence. The article also focuses on the way the novel criticises the indifference of men with power and authority, and the passivity and fear of social, political and religious leaders over the communal violence during and after partition. Last but not the least, the article also highlights the way the novel portrays the love between a Sikh boy and a Muslim girl where the Sikh boy Juggut Singh sacrifices his life in order to save his beloved Nooran and consequently saves the life of thousands of Muslims targeted for massacre. Khushwant Singh seems to have retained his faith in communal harmony and love despite the horror of partition.

Breaking Down of Religious and Communal Trust and Harmony The very first sentence of the novel refers to the devastating year of 1947 when the Indian subcontinent achieved independence from British rule. Even the weather itself symbolises the complicated and tensed scenario a newly independent nation was facing: "The summer of 1947 was not like other Indian summers. Even the weather had a different feel in India that year. It was hotter than usual, and drier and dustier. And the summer was longer ... there was no rain. People began to say that God was punishing them for their sins (Singh 1). After the declaration of independence, the entire country plunges into communal riots. Important cities like Calcutta (present Kolkata) are violently torn apart by riots causing the death of thousands of people. Instead of celebrating its independence, the entire country has to mourn the tragic death of its citizens. Both Hindus and Muslims blame each other for the destruction and bloodshed. Singh, however, provides a true, unbiased view of the event:

The fact is, both sides killed. Both shot and stabbed and speared and clubbed. Both tortured. Both raped. From Calcutta, the riots spread north and east and west: to Noakhali in East Bengal, where Muslims massacred Hindus; to Bihar, where Hindus massacred Muslims. Mullahs roamed the Punjab and the Frontier- Province with boxes of human skulls said to be those of Muslims killed in Bihar. (Singh 1-2) 
All those incidents clearly show the breaking down of trust and harmony among people of different religious communities.

Mano Majra was one of the very few places in the remotest corner of the border which were able to retain peace and order amidst volatile time. It was like a small oasis in the vast desert of communal atrocity and blood-thirsty. In this village, Muslims, Hindus and Sikhs have lived for centuries, showing mutual trust and respect. The harmonious co-existence of the villagers from different religious background and the local deity Deo, who is worshipped by the entire village irrespective of religion, caste and creed, became the symbol of communal harmony and the true spirit of India. However, these happy days did not last long; Singh shows how the peaceful life of the villagers got shattered overnight. For Muslims in Mano Majra, all the Sikhs became potential dangers and the name Pakistan became a sort of last resort: "Muslims sat and moped in their houses. Rumours of atrocities committed by Sikhs on Muslims in Patiala, Ambala and Kapurthala, which they had heard and dismissed, came back to their minds. They had heard of gentle women having their veils taken off, being stripped and marched down crowded streets to be raped in the market place" (Singh 127-128). Sikhs, on the other hand, recalled the words of the Guru and labeled Muslims as oppressor: "Never trust a Mussulman . . . what had they done to Sikhs? Executed two of their Gurus, assassinated another and butchered his infant children" (128). It is the sadistic violence on the other side of the border which caused a distinct division in the village. As Alok Bhalla states, "The partition had broken the covenant that men must make with men, castes with castes, religion with other tolerant religions, without which our survival is precarious and our enslavement by the barbarian is certain" (Bhalla xi). Muslims of Mano Majra had no other option but to leave their village and start for their new destination that is Pakistan.

Life in Mano Majra, which is extremely static, is controlled by the passing of train. Train, therefore, becomes the symbol of movement and thus makes a great impact on the life of the villagers. The train is the only source which connects the village with the other parts of the country and, therefore, provides a life-force to its people. However, gradually things started to change as partition began to take its toll on the villagers. The train, which was a source of movement and prosperity, becomes a ghostly and evil medium of carrying dead bodies loaded from both sides of the border. On an early September day, a ghost train carrying dead bodies arrived in Mano Majra from Pakistan: 
There were women and children huddled in a corner, their eyes dilated with horror, their mouths still open as if their shrieks had just then become voiceless. Some of them did not have a scratch on their bodies. There were bodies crammed against the far end wall of the compartment, looking in terror at the empty windows through which must have come shots, spears and spikes. There were lavatories, jammed with corpses of young men who had muscled their way to comparative safety. (Singh 90)

This scene is a graphic example of the atrocities of communal violence where the train appears as a ghost. This statement also shows the futile attempt of the passengers to save their lives from the enemies. As Shahane opines,

The train implies the movement of vast communities, torn from their links of nativity, from their places of birth and upbringing and areas of traditional growth in search of a New Jerusalem. It indicates the harrowing process of this change, the awful and ghastly experiences of human beings involved in a historical, objective and almost dehumanised process. (Shahane 21)

The dead bodies need to be cremated and are, therefore, removed from the train. Singh graphically describes the mass cremation scene and its shocking effect on the villagers: "Red tongue of flame leaped into the black sky. A soft breeze began to blow towards the village. It brought the smell of burning kerosene, then of wood. And then- a faint acrid smell of searing flesh. The village was stilled in a deathly silence" (Singh 88). After the departure of Muslims from Mano Majra, people's attention was diverted by the rise in the level of River Sutlej as if the river had turned into a death- bed: "Its turbid water carried carts with the bloated carcasses of bulls still yoked to them. There were also men and women with their clothes clinging to their bodies. ..." (Singh 150-151). River, thus, also becomes a silent witness of the communal mass-killing. This tragedy was put into the background when another train from Pakistan loaded with dead bodies arrived in Mano Majra where a bulldozer had to be brought to dig the earth in order to bury dead bodies. This instance is, however, the reflection of the brutality performed in the entire subcontinent. The train can, therefore, be seen as the harbinger of violence. 
Criticising the Role of Social, Political and Religious Authorities The depiction of the transformation occurring in the country shows the way(s) evil forces of hostility and hatred have replaced the moral and non-communal values of the nation. Even the politicians cannot do anything for a transformed country like India. Instead of realising the fact that their decision to divide the nation based on religion was a blunder, they were involved in playing mind games and blaming others. Even police and high administrative officials, who were bestowed with the responsibilities of maintaining law and order, were cherishing communal hatred in them and were involved in performing ruthless cruelties on both Indian and Pakistani people. The sub-inspector depicts the scene of horrible murder in Pakistan and is extremely angry at the ignorance of the national leaders in Delhi, declaring non-violence:

What is happening on the other side in Pakistan does not matter to them. They have not lost their homes and belongings; they haven't had their mothers, wives, sisters and daughters raped and murdered in the streets. Did your honour hear what the Muslim mobs did to Hindu and Sikh refugees in the marketplaces at Sheikhupura and Gujranwala? Pakistan police and the army took part in killings. Not a soul was left alive. (Singh 22)

The discussion between the sub-inspector and the deputy commissioner Hukum Chand shows the way even the authorities were actively involved in the game of violence.

Khushwant Singh criticises the administrative authorities by portraying the sub-inspector, the deputy commissioner and the government who intentionally or unintentionally help the communal violence spread like wildfire. The distrust in ideologies between communities, lack of confidence from the part of government officials, and improper control of power lifts the communal violence to the level of utter destruction. The administrative failure over the issue of partition is reflected in the words of the sub-inspector: "This new government is talking very loudly of stamping out all this after a few months in office of enthusiasm will cool down and things will go on as before. It is no use trying to change things overnight" (22). Singh sarcastically shows that the government whimsically decides to divide the nation overlooking the needs of India which in the time of partition was victim of poverty, illiteracy and administrative failure. The decision of partition and its effect on the innocent people of the sub-continent, who are unaware of the political diplomacy and blame game, shatters their longcherished dream of a better life after the independence. By exploring the innocence of the poor rural people, the novel exposes the ways in which 
innocent people without selfish motives get estranged in the communal violence. The question of the Muslim villagers of Mano Majra reflects their ignorance and, to some extent, indifference about national politics: "Freedom must be a good thing. But what will we get out of it? Educated people like you, Babusahib, will get the jobs the English had. Will we get more land or more buffaloes? . . . Freedom is for the educated people who fought for it. We were slaves of the English, now we will be slaves of the educated Indians - or the Pakistanis" (Singh 51). The above quotation clearly reflects the thought of the villagers that it will not make any difference in their wretched condition whether they are ruled by Indians or Pakistanis. Most of these people even do not know that the British have left and that the country is divided into Pakistan and Hindustan (India). In expressing his inability to stop violence in the wake of partition, Hukum Chand unleashes his anger on Indian government: "Where was the power? What were the people in Delhi doing? Making fine speeches in the assembly? Loud speakers magnifying their egos; lovely-looking foreign women in the visitor's galleries in breathless admiration" (Singh 185). Hukum Chand's words thus shed light on the long- spread communal violence where even government officials of both India and Pakistan are far away from the shelter of the political leaders.

The author's mockery of Indian social stratification, caste system and the poor people's blind faith in educated class is explicit through the character of Iqbal Singh. Iqbal, who calls himself a social worker sent to Mano Majra by his party in order to create awareness among villagers concerning partition, is severely criticised by Khushwant Singh. Although he comes to the village with the intention of reforming the innocent and uncivilised villagers, he, ultimately, proves to be a selfcentric person and a complete failure. As Kamal Mehta writes, "Iqbal is a nice satirical portraiture of the pseudo intellectual and the progressive elite class that criticizes all others but is itself impotent to contribute anything during the ordeal" (26-27). Iqbal Singh proves himself a man of word and not action. Although verbally he shows his willingness to sacrifice his life for villagers, in reality when the situation demands his sacrifice, he seems to be contemplating on profit and loss and the event exposes his hypocrisy. According to his philosophy, martyrdom pays off only when there are people to witness. He is ready to be imprisoned, thus achieving glory, but does not want to risk his life. When he was informed about the conspiracy of derailing the train carrying Muslims to Pakistan and was expected to take some steps against his being young and educated, he replies with startled innocence, "Me? Why me? What have I to do with it? I do not know these people. Why should they listen to a stranger" (Singh 24)? Starkly contrasting to the intention of making 
village people aware of the brutal political situation, he himself is afraid of facing them. He is an escapist and a coward who is busy in saving himself.

Khushwant Singh also criticises the role of government officials through the character of Hukum Chand who, although is dedicated to his official duty, seems to be unmoved by communal violence. Hukum Chand conveys sense of animalism. As a human being, he is corrupt, lecherous and hypocrite. His hypocrisy is revealed through his speech on the occasion of Muslim evacuation from Mano Majra: "Let them get out, but be careful they do not take too much with them. Hindus from Pakistan were stripped of all their belongings before they were allowed to leave overnight. Some on our side have not done too badly either" (Singh 32) . Hukum Chand's sexual comfort and enjoyment at the time of communal violence shows his preference to personal gain over national interest. He even indulges in perverted sexual intercourse when the entire country plunges into chaos and needs the help of the government officials like him. Again, his order to arrest Jugga and Iqbal in mere suspicion is an evidence of administrative failure.

\section{Retaining Faith in Communal Harmony and Love despite the Horror of Partition}

Unlike the so-called hero Iqbal, who wants to be in the newspaper headline, Juggut Singh shows his altruism at the very end of the novel where his physical love is transformed into something sublime. His gallant attempt to rescue his beloved Nooran, which was based on personal interest, turns into a national issue: to rescue the Muslim people. Dubey remarks, "In the sacrifice of Jugga Singh the novelist intends to inform the readers that the over powering urge for violence in men may be resisted only by the force of love, which drives the hero of the novel, Jugga Singh, to avert mass killings by laying down his own life" (Dubey 3). By sacrificing his life for humanity, Jugga establishes the fact that hatred and bitterness have helped nobody in the world, rather have created more chaos in the society. Through Jugga, Khushwant Singh also shows the way the grand affect of love turns a criminal into a humanist and helps him find his real self in the reader's heart. He becomes the upholder of love and communal harmony. It is the supreme power of love which has the ability to transform a criminal into an ambassador of peace.

The train which was planned to be sabotaged got safely reach to Pakistan because of the sacrifice of Juggut Singh. His transformation from a criminal to Messiah reminds us of Saint Valmiki who was also transformed into a sage from robber in his early age. He wrote the Holy Ramayan and as a result was remembered and worshipped by many people. Jugga seems to be very instrumental in translating his message 
of brotherhood and love into action. The central significance of the novel lies in serving humanity, the victory of love, and trust in the intrinsic goodness of human being in a crisis moment. Again, the love of Jugga (for Nooran) and the love of Hukum Chand (for Haseena, a teenage prostitute) belong to two completely opposite spheres: whereas Jugga's love for Nooran is based on strong passion, Hukum Chand's involvement with Haseena is temporary, apparent and casual. Shukhwant Singh seems to say that love is not mainly about sexual attraction, rather is also associated with sacrificing one's life for the love one(s) and even for humanity in general. Jugga's act of sacrificing his own life for the sake of humanity symbolises the beauty of love, suffering and sacrifice to get rid of the sordid world and to anticipate a utopian one. It is his sacrifice, supported by love, which brings back faith in the people of Mano Majra - peace and harmony of the tiny place was shattered by the communal violence originated from partition.

Jugga's love for Nooran and sacrificing his life for Muslims functions as a positive and dynamic force in the novel as it overcomes all the hurdles. While the men of power show their indifference, and religious authorities, social workers and government officials recoil in terror, it is Juggut Singh who courageously fights the evil and death. Jugga's selfless love and sacrifice reveals the failure of Hukum Chand as magistrate or Iqbal as social activist. Jugga's child, growing inside the womb of his beloved Nooran who moved to Pakistan, symbolises moral earnestness lacked by the politicians, socialists, bureaucrats and religious leaders of that time. Jugga's unbeatable courage and strength remove the gloom of unimaginable violence surrounding Mano Majra and from each and every part of Indian subcontinent, and label him as the symbol of love, sacrifice and goodness.

\section{Conclusion}

Even after more than seven decades of partition, people from both India and Pakistan are still haunted by the trauma of the event. Life after the event was never the same as life before the event. Khushwant Singh's Train to Pakistan tells the story which everyone wants to forget but cannot deny the brutal reality of our past. By presenting Mano Majra as the microcosm of the communal violence in the entire Indian subcontinent, Singh has successfully depicted the ugly phase of the nation's history. Singh shows the way the dawn of partition breaks down all communal and religious harmony and trust between people who are living together for centuries. Singh also criticises the role of political, social and religious authorities in initiating and spreading the violence. Singh shows how these leaders were busy in fulfilling their personal gain and how indifferent they were towards mass suffering. However, it is the self-sacrifice of Juggut Singh which starkly contrasts the eye for 
an eye, tooth for a tooth mentality of the mass people. Jugga's love with the Muslim girl Nooran and his attempt to save the lives of other Muslims cut across the religious barrier and seek to bridge the wide gap of communal hatred and violence. Placing high importance on love shows Khushwant Singh's optimistic vision of a peaceful future even after the dark days of communal atrocity.

\section{Works Cited}

Bhalla, Alok. Partition Dialogues. Oxford UP, 2006.

Butalia, Urvashi. The Other Side of Silence: Voice from the Partition of India. New Delhi: Penguin Books India, 1998

Dubey, S. K. Khushwant Singh: A Critical Study of His Novels. B. R. Publications, 1999.

Mehta, Kamal. "Train to Pakistan: A Study of the Partition and its Impact on the People."The Fictional World of Khushwant Singh, edited by Indira Bhatt, Creative Books, 2002, pp. 21-34.

Shahane, V. Anant. Khushwant Singh. New York: Twayne Publishers, 1972.

Singh, Khushwant. Train to Pakistan. Ravi Dayal Publishers, 2009. 